\title{
Direct DNA extraction method of an obligate parasitic fungus from infected plant tissue
}

L. Liu', C.L. Wang', W.Y. Peng', J. Yang1, M.Q. Lan', B. Zhang ${ }^{1}$, J.B. Li², Y.Y. Zhu' ${ }^{1}$ and C.Y. Li ${ }^{1}$

${ }^{1}$ Key Laboratory of Agro-Biodiversity and Pest Management of Education Ministry of China, Yunnan Agricultural University, Kunming, Yunnan, China

${ }^{2}$ Agricultural Environment and Resources Research Institute, Yunnan Academy of Agricultural Sciences, Kunming, Yunnan, China

Corresponding author: C.Y. Li

E-mail: licheng_yun@163.com

Genet. Mol. Res. 14 (4): 18546-18551 (2015)

Received September 18, 2015

Accepted November 10, 2015

Published December 28, 2015

DOI http://dx.doi.org/10.4238/2015.December.28.1

ABSTRACT. Powdery mildew and rust fungi are obligate parasites that cannot live without host organisms. They are difficult to culture in synthetic medium in the laboratory. Genomic DNA extraction is one of the basic molecular techniques used to study the genetic structure of populations. In this study, 2 different DNA extraction methods, Chelex-100 and cetyltrimethylammonium bromide (CTAB), were used to extract DNA from euonymus powdery mildew and Puccinia striiformis f. sp Tritici. Polymerase chain reaction was carried out with a race-specific-marker rDNA-internal transcribed spacer sequence. Both DNA extraction methods were compared and analyzed. The results showed that both Chelex-100 and CTAB were effective for extracting genomic DNA from infected plant tissue. However, less DNA was required for the Chelex-100 method than for the CTAB method, and the Chelex-100 method involved fewer steps, was simpler and safer, and did not require organic solvents compared to the CTAB method. DNA quality was evaluated by polymerase chain reaction, and the results showed that genomic DNA extracted using the Chelex-100 method was better than that using CTAB method, and was sufficient for 
studying the genetic structure of population.

Key words: Chelex-100 method; DNA extraction; Puccinia striiformis f. sp tritici

\section{INTRODUCTION}

Rust and powdery mildew are both obligate parasitic fungi that must obtain nutrients from the living host, have a strong parasitic capacity, and cannot be cultured under synthetic medium propagation. With the development of molecular biology techniques, particularly polymerase chain reaction (PCR), an increasing number of researchers have studied the related proteins and DNA of obligate parasite fungi-host interactions, such as powdery mildew and rust. PCR amplification is based on complete extraction of genomic DNA. Several techniques have been used to isolate fungal DNA, such as cetyltrimethylammonium bromide (CTAB), sodium dodecyl sulfate extraction, urea extraction, and benzyl chloride extraction, generally by grinding or chemical methods to remove the cell walls, followed by organic solvent extraction (Chen et al., 2011). These methods have disadvantages such as complicated steps and their requirement of large biomass. The latter limitation is particularly prominent for obligate parasitic fungi, which cannot be cultured in artificial medium. Before extracting DNA, single-spore stack separation, inoculation, and propagation of stripe rust on susceptible variety are required to obtain a sufficient number of pathogenic fungi with thick cell walls, making DNA extraction more difficult compared with this process in general fungal. The reported methods for extracting DNA from parasitic fungi require large amounts of pathogenic fungi (Han et al., 2006; Zheng et al., 2008), involve complicated operations, and are limited by time and space (Zhang et al., 2010; Zhuang et al., 2011). Therefore, it is essential to develop an efficient and fast method for DNA extraction from obligate parasitic fungi that require low amounts of sample.

Chelex-100, an ion-chelating resin consisting of a styrene-stilbene copolymer, which may cause membrane rupture, promote DNA release from cells, and prevent DNA degradation, has been widely used to obtain evidence samples from small amounts of blood, whole blood, tissue forensic plaques, fine spots, and bones (Yang et al., 2008; Liu et al., 2009; Yang et al., 2009; Xu et al., 2012; Wang et al., 2012). This method has also been useful for extracting DNA from pathogens (Chen et al., 2011; Zhou et al., 2011; Wen et al., 2011), but remains limited. In this study, genomic DNA from Euonymus japonicus powdery mildew and wheat stripe rust from diseased plant tissue was isolated using the Chelex-100 method and CTAB method and detected using fungal ribosomal rDNA-internal transcribed spacer (ITS) primers and PCR. We found that the Chelex-100 method showed several advantages over the CTAB method, both in operation and in DNA quality.

\section{MATERIAL AND METHODS}

\section{Materials}

Materials used in this experiment for the test were collected directly from the wild and then air-dried. Ten parts E. japonicus powdery mildew and 10 parts Puccinia striiformis $\mathrm{f}$. $\mathrm{sp}$ tritici samples were prepared. These samples were visible on the distribution of pathogens, air-dried, and stored at room temperature.

Fungal ribosomal rDNA-ITS primers (F: 5'-TCCGTAGGTGAACCTGCGG-3', R: 5'-TCCTC CGCTTATTGATATGC-3') (Chen et al., 2007) were synthesized by Invitrogen Corporation (Carlsbad, CA, USA). 


\section{Methods}

\section{Reagents}

Reagents required for the CTAB method included DNA extraction buffer (50 mMTris- $\mathrm{HCl}$, $\mathrm{pH}$ 8.0, $0.7 \mathrm{mM} \mathrm{NaCl}, 10 \mathrm{mM}$ EDTA, pH 8.0, 24:1 chloroform/isoamyl alcohol, isopropanol, hexanol, and $0.1 \%$ Tris, $0.002 \%$ EDTA). The Chelex-100 method required $20 \%$ Chelex- 100 .

\section{DNA extraction}

Powdery mildew and rust DNA were extracted using the Chelex-100 method and CTAB method. The detailed methods and procedures are shown in Table 1. In the process of extracting DNA from the infected plant tissue with the CTAB method, we aimed to select the samples with a large lesion and multiple pathogens. When the lesion is relatively small and with a lower number of pathogens, the Chelex-100 method was used for extraction. Five samples were included in each group. The samples' detailed information are shown in Figure 1.

\section{PCR detection of DNA extraction conditions}

Ten parts plant pathogen DNA samples were extracted and used as a template. Fungal ribosomal rDNA-ITS primers were used for PCR amplification. The total volume of the PCR amplification system was $25 \mu \mathrm{L}$, including $10 \mu \mathrm{L}$ supperMix (Biotech, Beijing, China), $1 \mu \mathrm{L}$ primer, $2 \mu \mathrm{L}$ (15-20 ng) DNA template, and $12 \mu \mathrm{LddH} \mathrm{d}_{2} \mathrm{O}$. The reaction conditions were $94^{\circ} \mathrm{C}$ for $3 \mathrm{~min}, 94^{\circ} \mathrm{C}$ for $50 \mathrm{~s}, 53^{\circ} \mathrm{C}$ for $1 \mathrm{~min}$, and $72^{\circ} \mathrm{C}$ for $1 \mathrm{~min}$ for 30 cycles, followed by $72^{\circ} \mathrm{C}$ for $10 \mathrm{~min}$. PCR products were detected on a $1.5 \%$ agarose gel.

\section{RESULTS}

\section{Comparison of DNA extraction methods}

Comparing the Chelex-100 method with the CTAB method for DNA extraction, the results showed that grinding, bath, extraction, precipitation, washing, drying, and dissolution were essential requirements for the entire process of the CTAB method. Tris- $\mathrm{HCl}, \mathrm{NaCl}, \mathrm{EDTA}$, chloroform/isoamyl alcohol (24:1), isopropanol, and hexanol were the basic reagents used. The time required for extraction of a sample was 85.5 min or more. Extraction using Chelex-100 required bacteria spores or mycelium from the plant tissue and a water bath to wash or scrape down the samples in 2 steps. Required reagents included only $20 \%$ Chelex- 100 . The time required to extract the sample was less than $9 \mathrm{~min}$, accounting for $1 / 9$ the time required for the CTAB method. The sample volume, reagents, procedures, and time spent were lower for the Chelex-100 method compared to the CTAB method. Thus, the Chelex-100 method for extracting wheat stripe rust pathogen DNA was must simpler than the CTAB method. Therefore, compared with the CTAB method, the Chelex-100 method was superior in the aspects of sample volume, reagents, procedures, and time requiredfor extraction of DNA from the obligate parasitic fungus from infected plant tissue. 
Table 1. Comparisonof2 methods of DNAextraction.

\begin{tabular}{|c|c|c|c|c|}
\hline \multirow[t]{2}{*}{ Main procedure } & \multicolumn{2}{|l|}{ CTAB method } & \multicolumn{2}{|l|}{ Chelex-100 method } \\
\hline & Method & Time required $(\mathrm{min})$ & method & Time required $(\mathrm{min})$ \\
\hline $\begin{array}{l}\text { Requirement } \\
\text { of samples }\end{array}$ & $\begin{array}{l}\text { Fresh or dried whole plant } \\
\text { leaves were covered with } \\
\text { pathogenic fungi }\end{array}$ & - & $\begin{array}{l}\text { Fresh or dried lesions } \\
\text { with } 5-\mathrm{mm}^{2} \text { visible pathogen } \\
\text { samples were selected. }\end{array}$ & - \\
\hline Grinding & $\begin{array}{l}\text { and then placed in the mortar } \\
\text { that was filled with liquid nitrogen, } \\
\text { and thenfast-grinded until the } \\
\text { leaves were pulverized. Liquid } \\
\text { nitrogen was added during this period. }\end{array}$ & $5-10$ & $\begin{array}{l}\text { The visible pathogen on } \\
\text { the plant was repeatedly } \\
\text { smeared using the } 10-\mu \mathrm{L} \\
\text { tips with } 5 \mu \mathrm{L} 20 \% \\
\text { Chelex- } 100 \text { lessons. } \\
\text { Pathogen was washed from }\end{array}$ & 1 \\
\hline Water bath & $\begin{array}{l}\text { The resulting powder was added } \\
\text { to } 1.5 \text {-mL centrifuge tubes, and } \\
\text { preheated DNA extraction buffer } \\
(50 \mathrm{mMTris}-\mathrm{HCl}, \mathrm{pH} 8.0 ; 0.7 \mathrm{M} \mathrm{NaCl} \text {; } \\
10 \mathrm{mM} \text { EDTA, pH } 8.0 \text { ) was quickly } \\
\text { added. The solution was placed in a } \\
65^{\circ} \mathrm{C} \text { water bath for } 20-60 \text { min. }\end{array}$ & $20-60$ & $\begin{array}{l}\text { The pathogen was then transferred } \\
\text { into a } 1.5 \text {-mL centrifuge tube } \\
\text { containing } 40 \mu \mathrm{L} 20 \% \text { Chelex-100 } \\
\text { and mixed. Boiling water was } \\
\text { added for } 2 \text { min. The mixture } \\
\text { was vortexed and shaken for } \\
10-30 \mathrm{~s} \text {. After incubation in a water } \\
\text { bath for } 5 \text { min, the supernatant } \\
\text { could be used as a template for PCR. }\end{array}$ & $7.5-8$ \\
\hline Extraction & $\begin{array}{l}\text { After cooling to room temperature, } \\
\text { an equal volume of } \\
\text { chloroform/isoamyl alcohol }(24: 1) \\
\text { was added, and the mixture was } \\
\text { gently shaken and centrifuged at } \\
12,000 \mathrm{~g} \text { for } 10 \text { min. The mixture } \\
\text { was extracted } 2-3 \text { times. }\end{array}$ & 10 & No & \\
\hline Precipitation & $\begin{array}{l}\text { The supernatant was removed in anothe } \\
\text { centrifuge tube and mixed with } 400 \mu \mathrm{L} \mathrm{cc} \\
\text { isopropanol. The mixture was } \\
\text { placed at }-20^{\circ} \mathrm{C} \text { for } 30 \text { min- } 2 \mathrm{~h} \text {, } \\
\text { and then centrifuged at } 12,000 \mathrm{rpm} \\
\text { for } 10 \mathrm{~min} \text {. The supernatant was discard }\end{array}$ & 1.5- $\mathrm{mL} 40-130$ & No & \\
\hline Washing & $\begin{array}{l}\text { The precipitate was washed twice } \\
\text { with } 70 \% \text { alcohol. }\end{array}$ & $0.5-1$ & No & \\
\hline Dry & $\begin{array}{l}\text { Samples were dried on a bacteria-free } \\
\text { table for } 5-30 \mathrm{~min} \text {. }\end{array}$ & $5-30$ & No & \\
\hline Dissolve & $\begin{array}{l}\text { Samples were dissolved in } 20 \mu \mathrm{L} \text { TE. } \\
\text { The product could be used for PCR } \\
\text { amplification after adjusting the } \\
\text { concentration. }\end{array}$ & 5 & No & \\
\hline Total & 7-9 steps & $85.5-246$ & 2 steps & $8.5-9$ \\
\hline
\end{tabular}

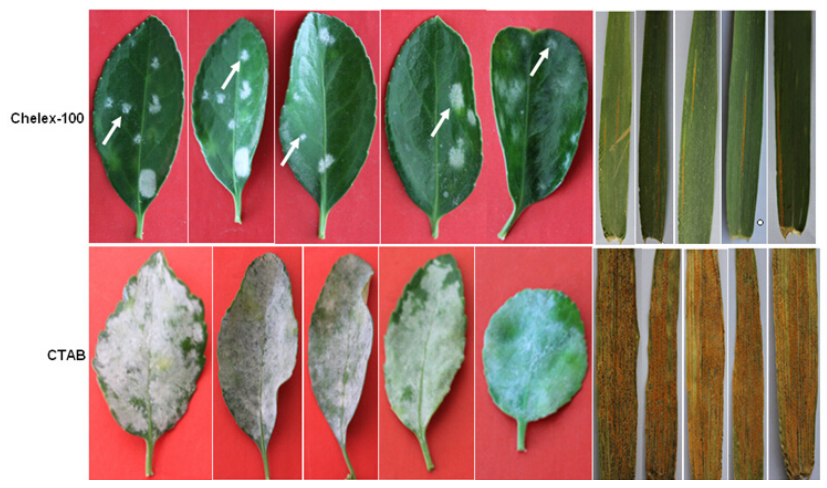

Figure 1. Samples characteristics, five samples were included in each group. 


\section{PCR amplification for DNA detection}

The DNA samples of wheat stripe rust, euonymus powdery mildew, and small wheat smut were extracted using the Chelex-100 and CTAB methods and detected using fungal ribosomal rDNA-ITS primers. The rDNA-ITS fragment was produced by DNA amplification following the Chelex-100 and CTAB methods. The fragment size was approximately 680 base pairs (Figure 2), consistent with the expected result. Both the Chelex-100 and CTAB methods were used for DNA extraction of a fresh sample of E. japonicus powdery mildew. After PCR amplification, all electrophoretic bands were relatively clear; however, for naturally air-dried wheat stripe rust DNA samples, PCR amplification showed different results. The amplified bands obtained from Chelex-100 extraction of wheat stripe rust samples were neat and clear, while the amplified bands using the CTAB method were relatively clear, but the 9th and all amplified bands showed smearing.

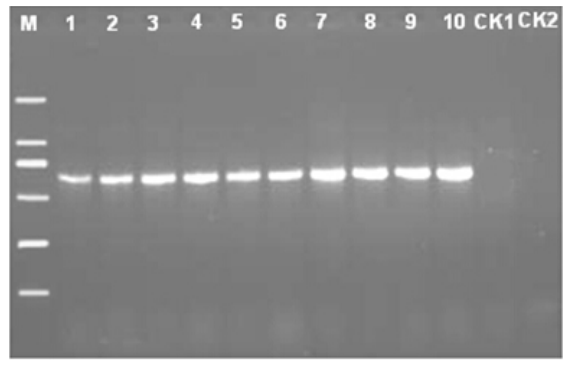

A

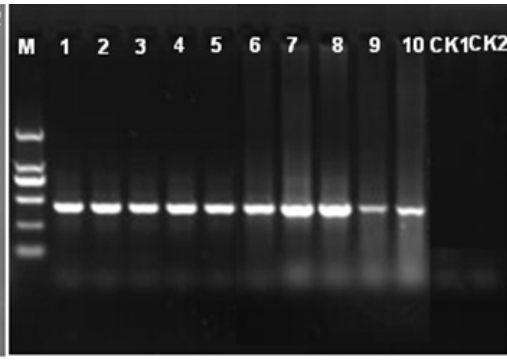

B

Figure 2. Agarose gelelectrophoresis of rDNA-ITS primers for Euonymus powdery mildew and wheat stripe rust. A. Agarose gelelectrophoresis of rDNA-ITS primers for Euonymus powdery mildew; B. Agarose gelelectrophoresis of rDNA-ITS primers for wheat stripe rust. M: DL2000 ladder maker. From smallest to largest, the molecular weightswere $100,250,500,750,1000$, and 2000 base pairs; I-5: DNA models of detected samples extracted using theChelex-100 method; 6-I0: DNA models of detected samples extracted using the CTAB method; CK1: water, negative control; CK1: negative control containing Chelex-100.

\section{DISCUSSION}

Rust and powdery mildew, which are both obligate parasite fungi, cannot be cultured in artificial culture media, limiting the application of molecular methods for studying the population genetic structure and physiological race changes. DNA extraction from parasitic fungi forms the basis of studies of population genetic structure and physiological variations in wheat stripe. However, some obligate parasitic fungi, such as wheat stripe rust, have thick cell walls and are rich in polysaccharides, proteins, and pigment impurities, making DNA extraction difficult. Previously reported extraction methods (Yu et al., 2005; Han et al., 2006; Zheng et al., 2008; Zhang et al., 2010; Chen et al., 2011; Zhuang et al., 2011) of parasitic fungal DNA require large amounts of pathogenic fungi, with complicated operation procedures and the limitations of time and space. Moreover, spores must be harvested, purified, and reproduced, which are time- and labor-consuming processes, and a low DNA yield is often obtained. In this study, we compared the Chelex-100 method and CTAB method for DNA extraction and then compared DNA quality. Our results showed that the Chelex-100 method was simple and rapid, involving 2 or 3 steps and less than 10 min. No organic solvents were used, reducing environmental pollution and the potential for harm to the operator. Furthermore, DNA extracted using Chelex-100 showed good quality and high yield. The DNA of 
wheat stripe rust extracted from $5-\mathrm{mm}^{2}$ diseased leaves could be used for 50 PCRs $(25-\mu \mathrm{L}$ reaction system) and thus the quality of the DNA was useful for PCR-based genetic research. DNA extracted using the CTAB method contained the DNA of plant tissues, which may directly affect additional studies on the population genetic structure. Studies of downy mildew and smut showed that various samples can be examined simply by changing the demand, bath time, and oscillation intensity and frequency based on sample purity and the specific situation. The DNA from most non-obligate parasitic fungi (rice blast fungus, Exserohilum bacteria, etc.) that can be isolated by CTAB can also be extracted using Chelex-100, indicating that Chelex-100 was more efficient and had a wider scope. Thus, diseased samples collected from the field can be used directly, reducing the amount of sample time and labor required for bacterial propagation, and improving the timeliness and representation of the pathogen population structure analysis. Our results contribute to the development of control strategies in the field. In conclusion, Chelex-100 can be used as part of a simple and efficient DNA extraction method.

\section{REFERENCES}

Chen JL, Huang XL, Wu AD, et al. (2011). An efficient extraction method of pathogenic fungus DNA for PCR. Mycosystema 30: 147-149.

Chen JS and Zheng Cf. (2007). Application of ITS sequences in fungi classification and identification. J. Anhui Agricult. Sci. 35: 3785-3786, 3792.

Han B, Lin RM, Cao YY, et al. (2006). Comparision of the methods of isolating wheat yellow rust genomic DNA. Chin. Agricult. Sci. Bul. 22: 81-83.

Liu YJ, Shi SX and Gao LB (2009). One case of Magnetic beeds Chelex-100 method to detect soil semen stains DNA. J. Forensic Med. 25: 479.

Wang HP, Wang XL, Yang W, et al. (2012). An optimized DNA extraction method for costal cartilage by using protinase $\mathrm{K}$ and Chelex-100. J. Forensic Med. 27: 54-55.

Wen J, Chen HW, Hou XD, et al. (2011). Extraction of genomic DNA from powdery mildew by Chelex-100 method and cloning ITS2. J. Anhui Agricult. Sci. 39: 22204-22205.

Xu DD, Huang H, Zhang MY, et al. (2012). The study about DNA extraction of whole blood by reducing Chelex-100 volume. J. Chengde Medi. Coll. 29: 69-70.

Yang D, Liu C, Xu QY, et al. (2008). Trace DNA testing oral exfoliated cells for examination. J. Forensic Med. 24: $126-128$.

Yang D, Liu C, Xu QY, et al. (2009). Real time quantificational study of DNA extracted by Chelex-100 from epithelial cells samples. Forensic Sci. Technol. 5: 30-31.

Yu ZD, Gao AQ and Cao ZM (2005). A minimal and rapid method for DNA extraction from uredinium of rust fungi. Lett. Biotechnol. 16: 48-50.

Zhang Q, Li ZY, Li JB, et al. (2010). Isolation of small amount DNA of Puccinia striiform is from wheat. Southwest China J. Agricult. Sci. 23: 1887-1890.

Zheng DY, Zheng M, Liu TG, et al. (2008). Wheat rust urediospore DNA extraction method research. Plant protection science and technology innovation and development, the Chinese society of plant protection in 2008 academic essays. ZhongGuo Zhi Wu Bao Hu Xue Hui 507-514.

Zhou SQ, Huang XL, Huang DY, et al. (2010). A rapid method extracting DNA from action mycetes by Chelex-100. Biotechnol. Bull. 2: 123-125.

Zhuang H, Yue HM, Zheng WM, et al. (2011). Extraction method of large genomic DNA for wheat stripe rust. Mycosystema 30: 817-821. 